\title{
Albanerpetontidae from the late Pliocene (MN 16A) Csarnóta 3 locality (Villány Hills, South Hungary) in the collection of the Hungarian Natural History Museum
}

\author{
Zoltán Szentesi ${ }^{1}$, Piroska PazonyI² \& Lukács MÉSZÁRos ${ }^{3}$ \\ ${ }^{1}$ Department of Palaeontology and Geology, Hungarian Natural History Museum, \\ H-1083 Budapest, Ludovika tér 2, Hungary.E-mail: crocutaster@gmail.com \\ ${ }^{2} M T A-M T M-E L T E$ Research Group for Palaeontology \\ H-1083 Budapest, Ludovika tér 2, Hungary.E-mail: pazonyi@nhmus.hu \\ ${ }^{3}$ Department of Palaeontology, Eötvös Loránd University, \\ H-1117 Budapest,Pázmány Péter sétány 1/C,Hungary.E-mail:lgy.meszaros@gmail.com
}

\begin{abstract}
Based on cranial and jaw elements, the presence of Albanerpeton pannonicum species (Allocaudata: Albanerpetontidae) was noticed from the late Pliocene Csarnóta 3 locality (Villány Hills). Since it is considered a poor fossil site, it had not been sufficiently studied. These fossils represent the geologically youngest record of the species from Hungary. Though, the Csarnóta 3 albanerpetontid assemblage is small the bones are well preserved, and all are informative on species or at least on genus level. The red coloured bone-bearing deposits and the preservation quality of bones are very similar to the uppermost strata (4-1) of the Csarnóta 2 palaeovertebrate locality. The study of small mammal fauna also suggests this correlation, as well as explains the age of the site. The studied vertebrate fauna forms a transition between the woodland and steppe wildlife. With 17 figures and 3 tables.
\end{abstract}

Key words - Albanerpeton, Albanerpetontidae, late Pliocene, small mammals, taphonomy, Villány Hills

\section{INTRODUCTION}

Albanerpetontidae are a Middle Jurassic - late Pliocene clade of salamander-like lissamphibians that are closely related to anurans and salamanders (e.g. Fox \& Naylor 1982, McGowan \& Evans 1995, Gardner 2001, Delfino \& SALA 2007, GARDNER \& BÖHME 2008), while at present some researchers think that the caecilians originate from another branch of amphibians (ANDERSON $e t$ al. 2008, MARJANOvić \& LAURIN 2013). Albanerpetontidae are known mostly as isolated bones and rare partial skeletons from Europe, the North American Western Interior, Middle Asia, and Morocco (northern Africa) (see GARDNER \& BöHme 2008: Table 2; Szentesi et al. 2013: Table 1). The known temporal range 
of this clade extends from ca. $165 \mathrm{Ma}$, from the first record in the early Bathonian (Middle Jurassic) (e.g. Evans \& Milner 1994) to the late Pliocene (Delfino \& SALA 2007). Throughout this period albanerpetontids maintained a conservative body structure (e.g. SWEETMAN \& GARDNER 2013). The recognition of taxonomically significant differences in the morphology of the jaws and frontals permitted the identification of four genera (Albanerpeton, Anoularpeton, Celtedens and Wesserpeton) which include twelve species (see GARDNER \& BöHME 2008, Szentesi et al. 2013). The type genus, Albanerpeton Estes et Hoffstetter, 1976 includes five species from the Early Cretaceous - late Paleocene of the North American Western Interior and two species from the middle Miocene - late Pliocene period of Europe (SWEETMAn \& GARDNER 2013). The geologically youngest Albanerpeton is currently the A. pannonicum Venczel \& Gardner, 2005, which is known from the early Pliocene of Hungary (MN 15, Ruscinian, Csarnóta, Villány Hills) (VENCZEL \& GARDNER 2005) and its geographical range has been extended to the late Pliocene of Italy (MN 17, late Villanyian, Rivoli Veronese, Verona Province) (Delfino \& Sala 2007). Both were found in fissure infills. The species was described by VenCzel \& GARDNER (2005) based on isolated and partly articulated bones, and in a later work MADDIN et al. (2013) also described a well preserved neurocranium.

The Csarnóta paleovertebrate localities (1-4) were discovered by Móric Pálfy at the beginning of the $20^{\text {th }}$ century. Encouraged by him, Tivadar Kormos collected fossils mainly from Csarnóta 2 between 1910 and 1930. From the mid1950s to 1958, Miklós Kretzoi and Dénes Jánossy made extensive investigations of the localities of Csarnóta. They preferred the fossiliferous Csarnóta 2 locality but they also collected from the Csarnóta 1 and 3-4 sites, which are relatively poor in vertebrate fossils. According to Kretzoi and Jánossy the geological ages of Csarnóta 1-3 are represented by the Csarnótan biostratigraphic stage, while Csarnóta 4 is younger than the others (JÁNOSSY 1986). In the vertebrate fauna of this locality the snake fossils are dominant, in particular the top of this series is full of snake vertebrae. The appearance of the advanced Mimomys and the replacement of some small mammals (for example Cricetinus by Allocricetus) suggest that these vertebrate assemblages are close to the Villanyian (KRETZOr 1962). This paper is the first report on the albanerpetontid fossils of the Csarnóta 3 site.

\section{GEOLOGY, MATERIAL AND METHODS}

The studied locality is located at Cser Hill, about $1.5 \mathrm{~km}$ south of the village of Csarnóta in the Villány Hills, in South Hungary (Fig. 1). Csarnóta 1-3 are red clay columns which were fissure infills in the formerly mined Triassic limestone, while Csarnóta 4 consists of cave deposits (JánOssy 1986). These red clay depos- 
its belong to the lower part of the Tengelic Red Clay Formation with no or less than $5 \%$ carbonate content and the disordered kaolinite in these columns are typical of older Pliocene age of the Villány Hills. Their mineralogical composition indicates a warm humid climate (KRetzor \& Pécsi 1982, Viczián 2002). Based on mammalian fossils, the geological age of the Csarnóta 1-3 fissure infills is estimated to be early-late Pliocene. This is equivalent to the late Ruscinian

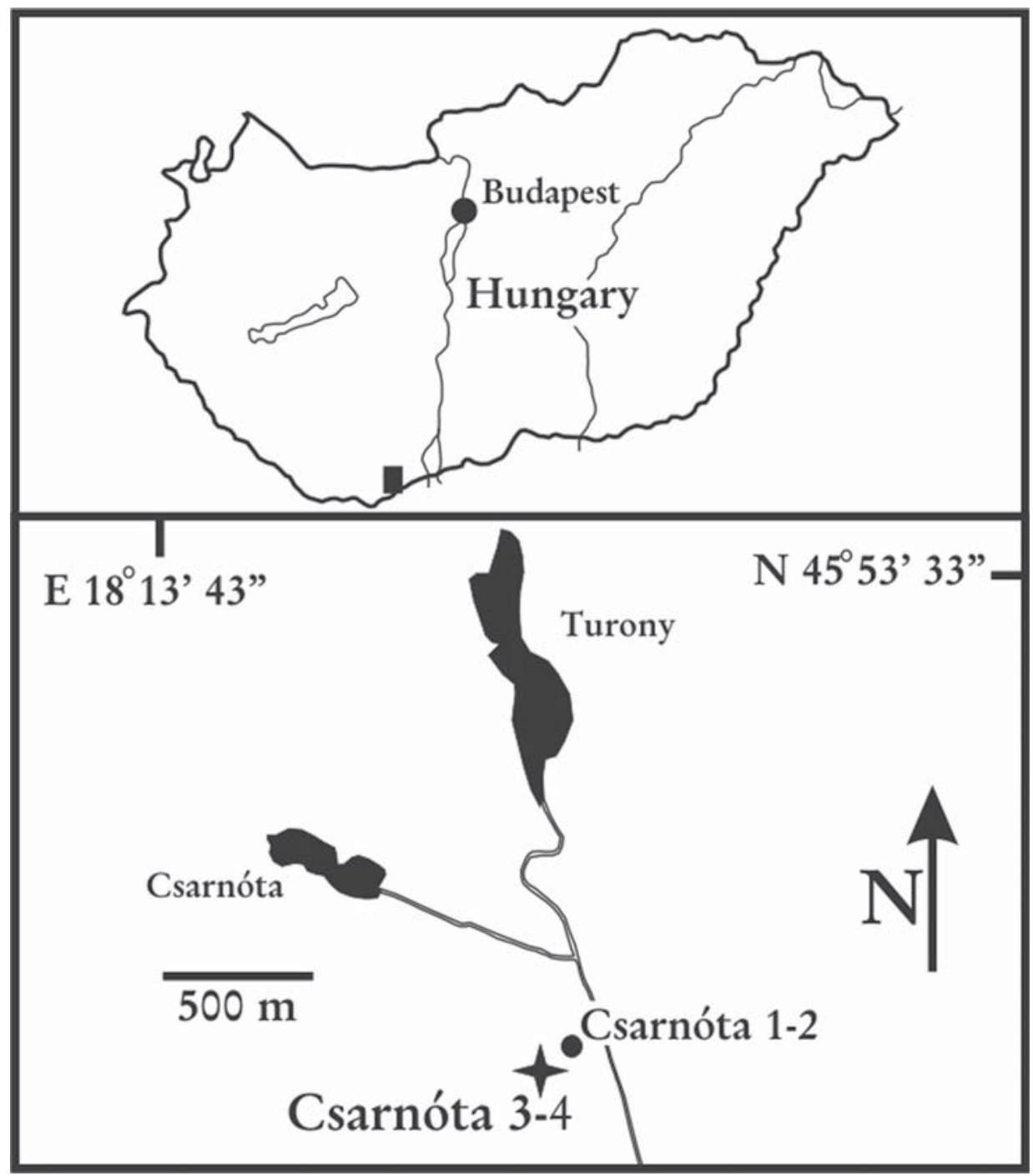

Fig. 1. Geographic location of the lower and upper Pliocene Csarnóta 1-3 palaeovertebrate localities and the younger (probably lower Pleistocene) Csarnóta 4 site (Villány Hills, Hungary) 
- early Villafranchian Land Mammal Age (e.g. Reumer 1984, JÁnossy 1986, ViCZIÁn 2002), which corresponds to the MN 15-MN 16A 'Mammals Neogene' (MN) zone (Augustí et al. 2001, MLíkovskÝ 2001). Csarnóta 3 lies next to Csarnóta 2 (approximately $5 \mathrm{~m}$; Kordos pers. comm.). Its fossiliferous deposits consist of well cemented red clay strongly mixed with tectonic breccias, where Kretzor (1962) distinguished 10 layers (the criteria of this subdivision are not known). The age of Csarnóta 3 is based on its small mammalian fauna and is contemporaneous with the upper part of the strata of site 2 (MN 16A). Likewise, the taphonomical observations refer to this age, as the remains have a dark brown discolouration in the sequences from the lower part of Csarnóta 2, while they are red in the upper part of it, like the Csarnóta 3 specimens. The below presented albanerpetontid fossils were unearthed from previously screen-washed deposits which were probably collected by Dénes Jánossy in 1978.

The osteological terms and measurements of jaws used here generally follow VenCZel \& Gardner (2005).

\section{SYSTEMATIC PALAEONTOLOGY}

Class Amphibia Linnaeus, 1758

Subclass Lissamphibia Haeckel, 1866

Order Allocaudata Fox et Naylor, 1982

Family Albanerpetontidae Fox et Naylor, 1982

Genus Albanerpeton Estes et Hoffstetter, 1976

\section{Albanerpeton pannonicum Venczel et Gardner, 2005}

(Figs 2-15)

Referred material - 3 right premaxillae (VER 2015.162.1.; 2015.241.1.; 2015.242.1.), 2 right maxillae (VER 2015.161.1.; 2015.245.) and 4 left maxillae (VER 2015.163.1.-2.; 2015.238.2.-3.), 1 left maxilla fused with lacrimal and jugal (VER 2015.239.1.), 12 right dentaries (VER 2015.161.2.; 2015.238.4.-8.; 2015.239.4.-6.; 2015.240.2.; 2015.241.2.; 2015.242.2.) and 2 left dentaries (VER 2015.240.3.; 2015.241.3.), 3 frontals (VER 2015.239.2.-3.; 2015.240.1.).

\section{TAPHONOMICAL OBSERVATIONS}

The specimens are isolated and incomplete ones, and show different qualities of fossilization. Most albanerpetontid fossils have clear, smooth and hard surfaces with red clay filling in their pores. Nevertheless, the surface of some bones is mostly glossy and encrusted with fine-grained sediment, which partial- 
ly fills the grooves and foramina. Consequently, these structures on these latter mentioned bones are difficult to interpret. Some bone coatings of manganese oxides form more or less large spots. The soluble manganese compounds are mobilized at the same time as the disintegrating of the limestone is produced and they are transported with water that infiltrates the sediment, but these precipitate with the variation of $\mathrm{pH}$, in this case on the surface of the fossilized bones. The environment of karst cavities (as for example Csarnóta 3) is characterized as wet, mildly alkaline and oxidizing, so the stable forms of iron and manganese oxide are easily transported with water. These precipitate on the surfaces of bones affected by $\mathrm{pH}$ changes due to variable amounts of rainfall (e.g. LópeZ-GonZÁLEZ et al. 2006).

\section{DESCRIPTION}

Premaxillae - Three isolated premaxillae are known from Csarnóta 3/6. The best preserved of these is the VER 2015.162.1. (Figs 2-3). The bone is small but it is relatively robust in build compared to similar sized albanerpetontids, for example Albanerpeton arthridion (e.g. GARDNER 1999, text-fig. 2, A-D). The grooves and flanges along the medial surface of this bone suggest that it was paired with another one in life (e.g. VenCZEL \& GARDNER 2005). The pars dorsalis is relatively low and broad. The laterodorsal notch is partially broken, but it is wide and was probably deep. The dorsal edge of the pars dorsalis is damaged; the laterodorsal edge bears low, indistinct ridges and grooves due to sutured contact with the nasal.

In labial view, the pars dorsalis is covered by a low dorsal 'boss', which is ornamented with irregular shallow pits, grooves and low ridges. On the labial surface of the premaxilla below the 'boss' the surface is rugged and external nutritive foramina are scattered below. Labially, the lateroventral corner of the premaxilla bears a seam surface for the lateral process of the maxilla.

In lingual view, the suprapalatal pit opens in moderate size on the medial part of the pars dorsalis, above the pars palatinum, and its outline is elliptical. A labiolingually low internal strut is equally present lateral and medial to the suprapalatal pit. The pars palatinum is a lingually broad shelf, and its lateral end is developed into a flange-like maxillary process. The pars palatinum bears a pronglike vomerine process near its medial end. The oval palatal foramen opens ventrally, midway on the pars palatinum and it joins the suprapalatal pit dorsally. The size of the palatal foramen is less than the diameter of the shaft of the teeth. The pars dentalis is moderately deep and it becomes shallower laterally.

Maxillae (Figs 4-7) - Six maxillae are preserved as isolated bones and one left maxilla is preserved fused with an incomplete lacrimal and jugal. All maxillae 
are covered lingually with fine sediment crust. These bones are moderately elongated and low. Near its anterior end, the pars dorsalis bears a dorsally protruding nasal process (Fig. 4) with a posteriorly concave margin. The pars dorsalis becomes shallower posteriorly and its dorsal surface from the posterior base of the nasal process is flattened toward the posterior end (the posteriodorsal end is broken on all bones) which were fused, in life, anteriorly with the lacrimal and posteriorly with the jugal (e.g. VENCZEL \& GARDNER 2005). The labial surface of the maxilla is plain and on its anterior part, from the base of the premaxillary lateral process to about the middle of the bone, there are tiny, oval nutritive foramina. The anteriorly projecting premaxillary lateral process is relatively short equally in lingual and labial views, and its anterior end is blunt (Fig. 4), or not
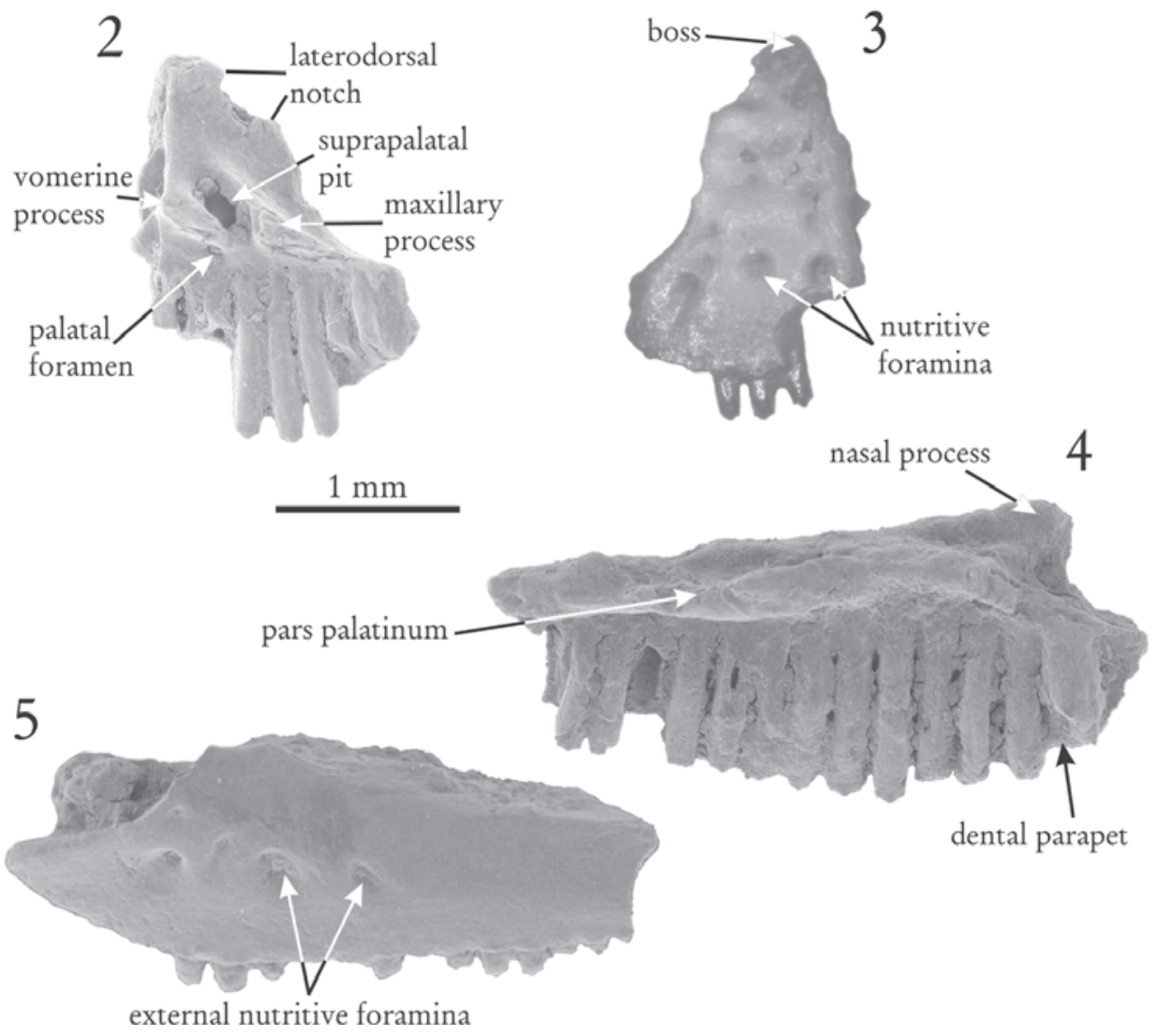

Figs 2-5. Premaxilla and maxillae of Albanerpeton pannonicum from the upper Pliocene of Hungary (Csarnóta 3 palaeovertebrate locality, Villány Hills). 2-3. right premaxilla (VER 2015.162.1., Csarnóta 3/6), lingual (2) and labial (3) views; 4. left maxilla (VER 2015.161.1., Csarnóta 3/3), lingual view; 5. left maxilla (2015.163.1., Csarnóta 3/9), labial view 
too acuminate (Fig. 5). Its length is subequal to its depth at the base. The pars palatinum is a lingually broad shelf, which anteriorly has a flange-like premaxillary dorsal process (Fig. 5; it is not figured in lingual view). The medial edge of the pars palatinum is slightly concave that formed, in life, the lateral margin of the narial opening (e.g. VenCzEL \& GARDNER 2005). The posterior part of the pars palatinum is broken on all maxillae. The pars dentalis is anteriorly deepest and becomes shallow posteriorly. Labially, the ventral margin of the pars dentalis
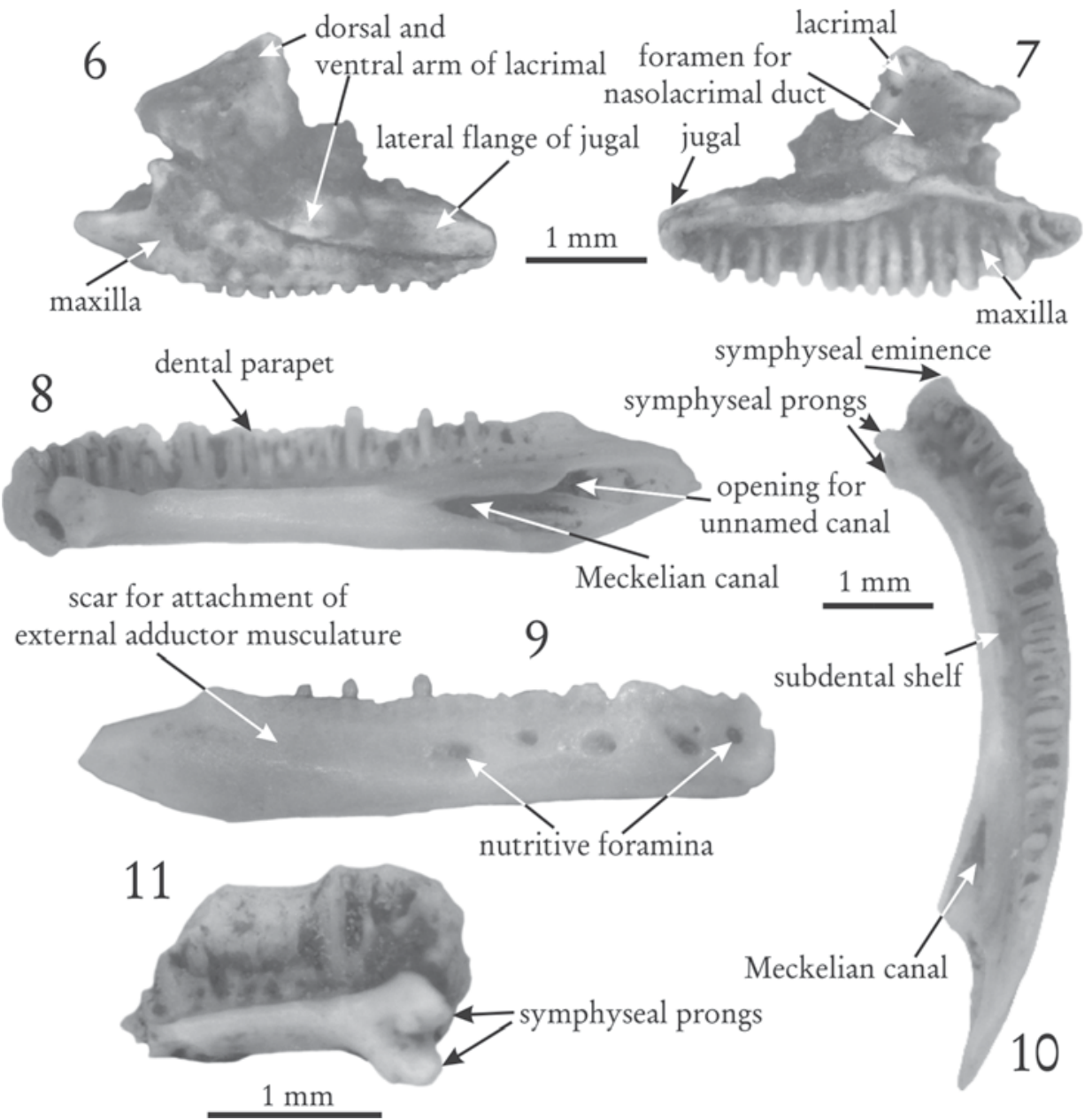

Figs 6-11. Maxillary arcades and dentaries of Albanerpeton pannonicum from the upper Pliocene of Hungary (Csarnóta 3 palaeovertebrate locality, Villány Hills). 6-7. left maxilla (VER 2015.239.1., Csarnóta 3/6), articulated with incomplete lacrimal and jugal, labial (6) and lingual (7) views; 8-10. right dentary (VER 2015.239.4.), lingual (8), labial (9) and occlusal (10) views; 11. left dentary (VER 2015.240.3.), lingual view 
is nearly straight. The anterior end of the tooth row is approximately in line with the anterior edge of the nasal process.

Dentaries (Figs 8-11) - 16 dentaries were unearthed from the locality but none of them is completely preserved. The dentaries are conspicuously curved labially in dorsal and ventral views. These bones are elongated and slightly taper anteriorly. The vertical symphysis is flattened anteriorly and posteriorly, and usually bears two symphyseal prongs that project medially and slightly posteriorly (Figs 10-11). The end of the symphysis is a swelling-like form, which protrudes labially. The dentary has mesiodistally compressed, highly pleurodont teeth. The tooth row extends for about the anterior three-quarters of the dentary. A dentary has a relatively tall dental parapet; an anteriorly relatively shallow subdental shelf. The dental parapet bears a slightly convex dorsal margin. The labial surface of the dentaries is not ornamented but bears external nutritive foramina that extend along the anterior half of the bone. Under these foramina, on the ventral surface of the bone there is a shallow, anteroposteriorly elongated recess, which is delimited with a low ridge. The Meckelian canal is closed lingually at the end of tooth row, while anteriorly it opens with a small foramen on the ventral part of the symphysis.

Frontals (Figs 12-15) - Only three incompletely preserved fused pairs of frontals are known from the studied deposits. The frontal which is not figured contains only the right part of the bone from the ventrolateral crest to the anterolateral process. All pairs of frontals are solidly fused along the midline, which is visible as a faint line ventrally on the bone. The fused frontals are approximately equilateral triangles in dorsal or ventral views. The spike-like, elongated internasal process projects anteriorly. On both sides, the shorter, prong-like anterolateral process is well developed. In the anterior part of the frontal, on the edge of the bone two slots open to either side of the midline. From these, the anteromedial slot opens between the internasal and the anterolateral processes, whereas the anterolateral slot, which has deeply recessed dorsal and ventral margins, lies more posteriorly and laterally, behind the anterolateral process.

Lacrimal (Figs 6-7) - A left maxilla from Csarnóta 3 is in articulation with a jugal and a lacrimal (VER 2015.239.1.). This incomplete left lacrimal is approximately U-shaped on its side, with an anteriorly directed apex. The dorsal and ventral arms of the lacrimal are separated by a broad, horizontally extending trough (filled with fine grained deposits) on the labial face. In life, the lower surface of the dorsal arm and the upper surface of the ventral arm collectively formed the anterior rim of the orbit (e.g. VENCZEL \& GARDNER 2005).

The dorsal arm of the lacrimal projects dorsally and slightly posteriorly, while the ventral arm of this bone extends posteriorly and slightly ventrally. The ventral side of the ventral arm of the lacrimal articulates with the dorsal margin of the pars dorsalis of the maxilla, from the distal end of the nasal process pos- 
teriorly to a point about two-thirds along the maxilla. The ventral arm of the lacrimal wraps ventrally on the labial surface of the maxilla and extends lingually onto the maxilla through the dorsal surface of the pars palatinum. The posterior end and the medioposterior edge of the ventral arm of the lacrimal do not connect with the maxilla, forming a gap lingually between these bones.

Jugal (Figs 6-7) - The jugal is not complete, its dorsal flange and posterior end are damaged. Based on its preserved part, the jugal is elongated. The lateral
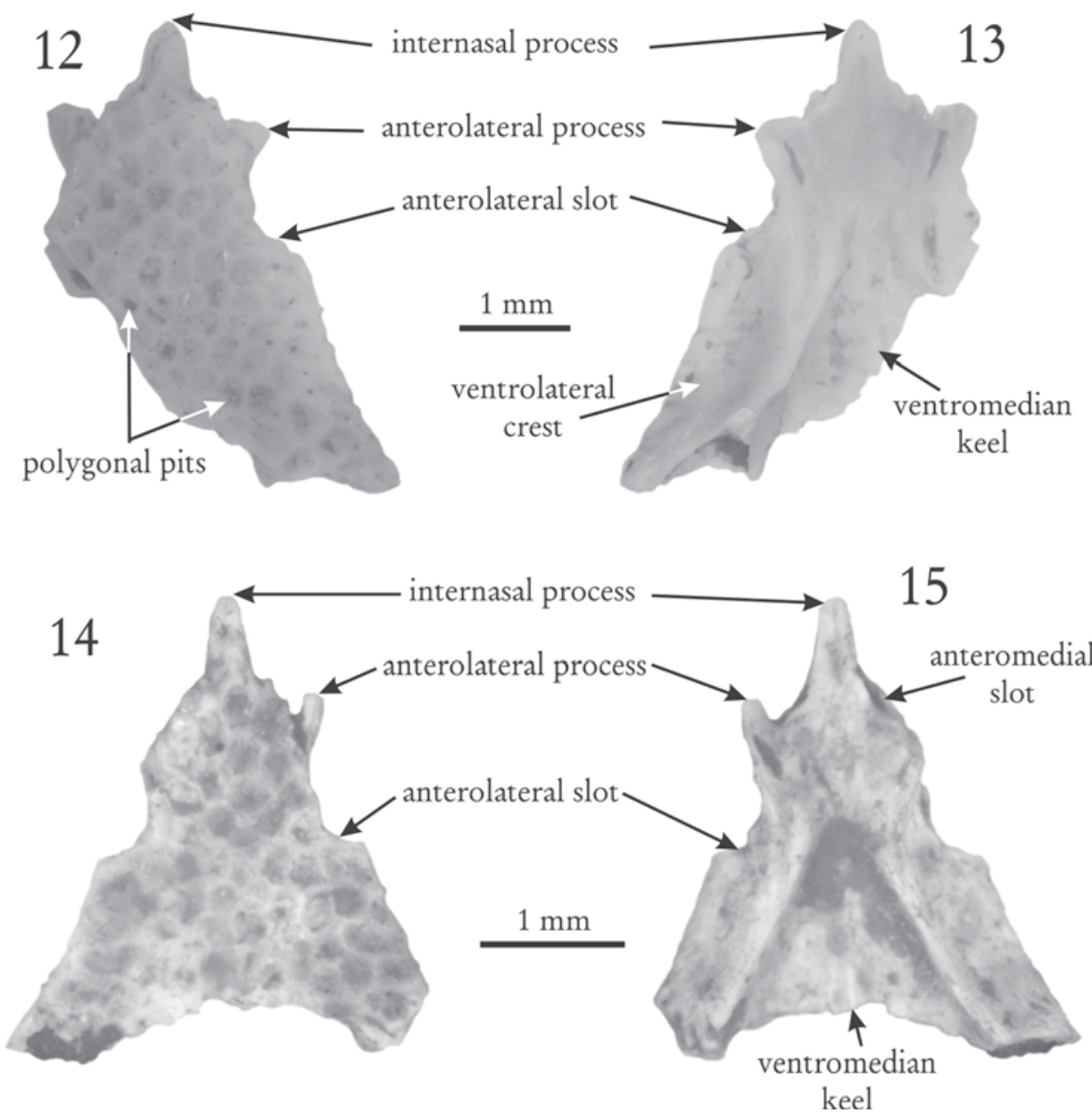

Figs 12-15. Fused frontals of Albanerpeton pannonicum from the upper Pliocene of Hungary (Csarnóta 3 palaeovertebrate locality, Villány Hills). 12-13. partially preserved frontal (VER 2015.239.2., Csarnóta 3/6), dorsal (12) and ventral (13) views; 14-15. incomplete frontal (VER 2015.240.1., Csarnóta 3/7), dorsal (14) and ventral (15) views 
flange is low; its labial surface is smooth. The anteriormost end of the jugal is solidly wedged between the underlying maxillary pars dorsalis and the overlying posterior end of the ventral arm of the lacrimal.

Remarks - The symphyseal prongs on the dentaries are autapomorphic for albanerpetontids (e.g. Fox \& NAYLOR 1982, GARDNER 2001). Based on the synapomorphies of the frontals (triangular in outline and moderately elongated) that is diagnostic for the genus Albanerpeton. The narrow and flattened median keel on the fused frontals is autapomorphic of $A$. pannonicum (VENCZEL \& GARDNER 2005). Beside this the robustly constructed premaxilla (compared to its size), the well-developed vomerine process on this bone, the relatively lateral process on the maxillae (with length subequal to depth at the base), the ventrally relatively straight dental parapet and the nearly aligned maxillary tooth row and anterior edge of the nasal processes also suggest that these bones are close to this species.

\section{PALAEOECOLOGICAL AND PALAEOBIOGEOGRAPHICAL NOTES}

The fossil record of the Albanerpeton genus extends from the middle or late Campanian to the late Pliocene in Europe (summarized by GARDNER \& BöHME 2008, Table 2). This suggests that it is a very conservative genus preserved in relatively conservative skeletal forms during this long geological time. The studies of the fossiliferous layers of Csarnóta 2 suggest that the palaeoenvironment changed from forest to grassland during the deposition of its 25 layers (e.g. JÁNOSSY 1986). Despite this process, the albanerpetontids appeared in all layers (VENCZEL \& GARDNER 2005). Conversely, the fauna composition of Csarnóta 2 is typical of humid forests (KRETzoi 1959, KRETzor \& PÉCSI 1982) with small mammals of Southeast Asian origin, while KRETzor (1962) wrote in another work that the upper levels of Csarnóta 2, as well as Csarnóta 1, 3 and 4 represent grassland-steppe faunal assemblages.

Compared with Csarnóta 2 the number of vertebrate fossils at Csarnóta 3 is very low but represents many taxa. Besides unidentifiable bone chips of larger mammals only few bones of small mammals are known, as well as bufonid remains and snake vertebrae described previously from the brecciate sediments. Despite the fact that few remains were found in the site, the small mammal fauna is quite substantial (Table 1). Insectivores, squirrel, dormouse, mole-rat, hamster, voles and mice equally occurred.

Ten Soricidae species were determined in the Csarnóta 3 fossil assemblage; all of them belong to the subfamily Soricinae. Five species (Sorex minutus Linnaeus, 1766; Deinsdorfia kordosi Reumer, 1984; Petenyia hungarica Kormos, 1934; Blarinella europaea Reumer, 1984; Zelceina soriculoides Sulimski, 1959) belong to the tribe Soricini. Blarinoides mariae Sulimski, 1959 and Mafia csarnotensis Reumer, 1984 can 
be classified as Blarinini. The other three forms appertain to different tribes (Episoriculus gibberodon (Petényi, 1864) - Soriculini; Beremendia fissidens (Petényi, 1864) Beremendiini; Paenelimnoecus pannonicus (Kormos, 1934) - Allosoricini).

In the relative groups of the shrews several Chiroptera, Erinaceomorpha and Talpidae species occurred in the Csarnóta 3 sample, but they are not discussed here. However, the study of the soricid species has a great importance providing relevant data on the stratigraphic position and the palaeoecology of the site.

In addition to the rich insectivore fauna, Arvicolinae and Muridae materials are also significant (Table 1). Six Arvicolinae species were determined in this assemblage, among which Mimomys stehlini Kormos, 1931 indicates the MN 16A (Mimomys hassiacus-Mimomys stehlini) Neogene mammal zone (after

Table 1. Small mammalian fauna of the Csarnóta 3 locality (MNI - minimum number of individuals)

\begin{tabular}{|c|c|c|c|c|c|c|c|c|c|c|c|c|}
\hline \multicolumn{13}{|c|}{ Small mammalian fauna of the Csarnóta 3 site (MNI) } \\
\hline layer & $3 / 1$ & $3 / 2$ & $3 / 3$ & $3 / 4$ & $3 / 5$ & $3 / 5 a$ & $3 / 6$ & $3 / 7$ & $3 / 8$ & $3 / 9$ & $3 / 10$ & $3 / 1-3$ \\
\hline Episoriculus gibberodon & & 1 & 1 & 1 & & & & & & & 1 & \\
\hline Blarinoides mariae & 1 & 2 & 1 & 2 & & 1 & 3 & 2 & 2 & 1 & 4 & 1 \\
\hline Beremendia fissidens & & & 2 & 2 & 1 & 1 & 3 & 1 & 1 & 1 & 2 & 1 \\
\hline Paenelimnoecus pannonicus & & 1 & 1 & & 1 & & 2 & & & & 1 & 1 \\
\hline Deinsdorfia kordosi & & 2 & & & 1 & & & & & 1 & & 1 \\
\hline Zelceina soriculoides & & & & 1 & & & & 1 & & & & \\
\hline Blarinella europaea & & & & & & & & & 1 & & 1 & \\
\hline Sorex minutus & & & 1 & & & & 1 & & & & & 1 \\
\hline Mafia csarnotensis & & 1 & & & & & & & & & & 1 \\
\hline Petenyia hungarica & & 1 & & & & & & & & & & \\
\hline Eutamias (?) sp. indet. & & & & & & & & & & & 1 & \\
\hline Dryomimus eliomyoides & & 1 & 1 & 1 & 1 & & & & & & 1 & 1 \\
\hline Prospalax priscus & & 1 & 1 & & & & 2 & 2 & 1 & 1 & 2 & 2 \\
\hline Cricetinus europaeus & & & 1 & & & & & & & & & \\
\hline Baranomys loczyi & & & & & & & & 1 & & & & \\
\hline Cseria gracilis & & & 1 & & 1 & 1 & & & & 1 & 2 & \\
\hline Dolomys nehringi & & 1 & 2 & 1 & 1 & & 1 & 2 & 1 & & 4 & 2 \\
\hline Dolomys milleri & & & & 1 & & 1 & & & & & & \\
\hline Propliomys hungaricus & & 2 & 2 & 1 & & 1 & 2 & 1 & & & 3 & 1 \\
\hline Mimomys stehlini & & & & & 1 & & & & & & & \\
\hline Micromys praeminutus & & 1 & & & & & 2 & & & & & \\
\hline Apodemus dominans & 1 & 4 & 7 & 6 & 2 & 3 & 7 & 8 & 3 & 2 & 10 & 4 \\
\hline Rhagapodemus frequens & & 5 & 3 & 1 & 1 & 1 & 2 & 1 & 1 & 1 & 1 & 2 \\
\hline
\end{tabular}


MEIN 1975). However, the two most common voles are Dolomys nehringi Kretzoi, 1956 and Propliomys hungaricus Kormos, 1934, similarly to the Csarnóta 2 site. The other voles (Baranomys loczyi Kormos, 1933; Cseria gracilis Kretzoi, 1956; Dolomys milleri Nehring, 1898) are represented by only few specimens in the material. The same three mice species (Micromys praeminutus Kretzoi, 1959; Apodemus dominans Kretzoi, 1959; Rhagapodemus frequens Kretzoi, 1959) found in this site were described by KRETzOI (1959) from the Csarnóta 2 locality.

The specific composition of the Csarnóta 3 Soricidae fauna is also very similar to that of the Csarnóta 2 locality. We have found all the well-determinable species which were mentioned by REUMER (1984) from that site (Table 2). Though the stratigraphical occurrences of some forms (for example Mafia csarnotensis, in Rzebik-Kowalska \& Popov 2005, etc.) have been emended since Reumer's studies, we can be sure of the similar ages of the two sites on the basis of the high number of concomitant shrews.

Table 2. Comparison of the Sorex fauna of the Csarnóta 2 and 3 localities. The data of Csarnóta 2 were given in REUMER (1984)

\begin{tabular}{|c|c|c|c|c|c|c|c|c|c|c|}
\hline locality/layer & 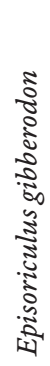 & 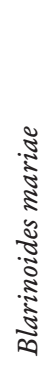 & 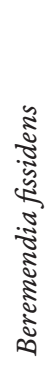 & 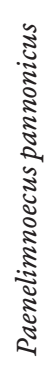 & 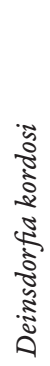 & 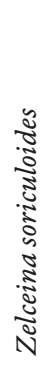 & 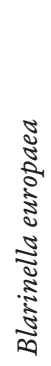 & 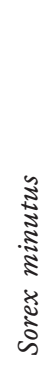 & 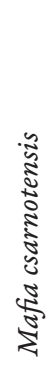 & 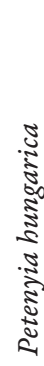 \\
\hline 2 & + & + & + & + & + & + & + & + & + & + \\
\hline $3 / 1$ & & + & & & & & & & & \\
\hline $3 / 2$ & + & + & & + & + & & & & + & + \\
\hline $3 / 3$ & + & + & + & + & & & & + & & \\
\hline $3 / 4$ & + & + & + & & & + & & & & \\
\hline $3 / 5$ & & & + & & + & & & & & \\
\hline $3 / 5 a$ & & + & + & & & & & & & \\
\hline $3 / 6$ & & + & + & & & + & & & & \\
\hline $3 / 7$ & & + & + & & & & & & & \\
\hline $3 / 8$ & & + & + & & & & + & & & \\
\hline $3 / 9$ & & + & + & & + & & & & & \\
\hline $3 / 10$ & + & + & + & + & & & + & & & \\
\hline $3 / 1-3$ & & + & + & + & + & & & + & + & \\
\hline
\end{tabular}


On the other hand, the ratio of the Csarnóta 3 shrew species is markedly different from that of Csarnóta 2 (Table 3; Fig. 16). The main difference is the higher number of the big sized forms (Blarinoides mariae and Beremendia fissidens) and the lower rate of Episoriculus gibberodon and Paenelimnoecus pannonicus at site 3 compared to site 2 . The variance can be caused by the fact that the layers of Csarnóta 3 are contemporaneous with the upper part of the strata of site 2, where the aforementioned rates occur, as well (see REUMER 1984, fig. 20; upwards from layer 12). This presumption is supported by the presence of Mafia csarnotensis and the taphonomical features.

Some of the shrew genera reported here are useful in the palaeo-ecotype reconstruction (REUMER 1984, RzEBIK-KowALSKA 1995). Sorex and Blarinella indicate a humid forest environment. The presence of open water is marked by Paenelimnoecus and probably Beremendia (Bot KA \& MÉszÁros 2014). Blarinoides and Petenyia are typified by REUMER (1984) as opportunist and ubiquitous genera.

While the typical steppe indicator Crocidura is not present in this sample, the real forests species (Sorex and Blarinella) are not frequent either (Fig. 16). The high rate of water-preferring forms indicates an open surface of a lake or a river, perhaps with forest or shrubby vegetation. At the same time we cannot exclude the presence of more open ecotypes in the wider surroundings because of the great number of opportunist forms.

The same can be observed in the case of rodents. The ratio of the Csarnóta 3 rodent families and subfamilies (Sciuridae, Gliridae, Spalacidae, Cricetinae, Arvicolinae, Rhagapodemus and Muridae) is very similar to the upper part of

Table 3. Comparison of the ratio of Sorex species in the Csarnóta 2 and 3 localities. The data of Csarnóta 2 are given by REUMER (1984)

\begin{tabular}{lcccc}
\hline \multicolumn{5}{c}{ Ratio of the Soricidae species (\%) } \\
species & $\begin{array}{c}\text { Csarnóta 2 } \\
\text { number of teeth }\end{array}$ & $\begin{array}{c}\text { Csarnóta 2 } \\
\text { number of condyles }\end{array}$ & $\begin{array}{c}\text { Csarnóta 3 } \\
\text { number of teeth }\end{array}$ & $\begin{array}{c}\text { Csarnóta 3 } \\
\text { MNI }\end{array}$ \\
\hline Episoriculus gibberodon & 38.4 & 39.6 & 6.3 & 6.6 \\
Blarinoides mariae & 18.4 & 8.0 & 53.2 & 32.8 \\
Beremendia fissidens & 14.3 & 6.8 & 23.9 & 24.6 \\
Paenelimnoecuspannonicus & 8.8 & 24.4 & 4.5 & 11.5 \\
Deinsdorfia kordosi & 7.1 & 6.1 & 4.5 & 8.2 \\
Zelceina soriculoides & 5.2 & 6.9 & 2.3 & 3.3 \\
Blarinella europaea & 3.0 & 2.5 & 0.9 & 3.3 \\
Sorex minutus & 1.8 & 1.7 & 2.3 & 4.9 \\
Mafia csarnotensis & 1.7 & 0.9 & 0.9 & 3.3 \\
Petenyia bungarica & 1.2 & 3.0 & 1.4 & 1.6 \\
\hline
\end{tabular}




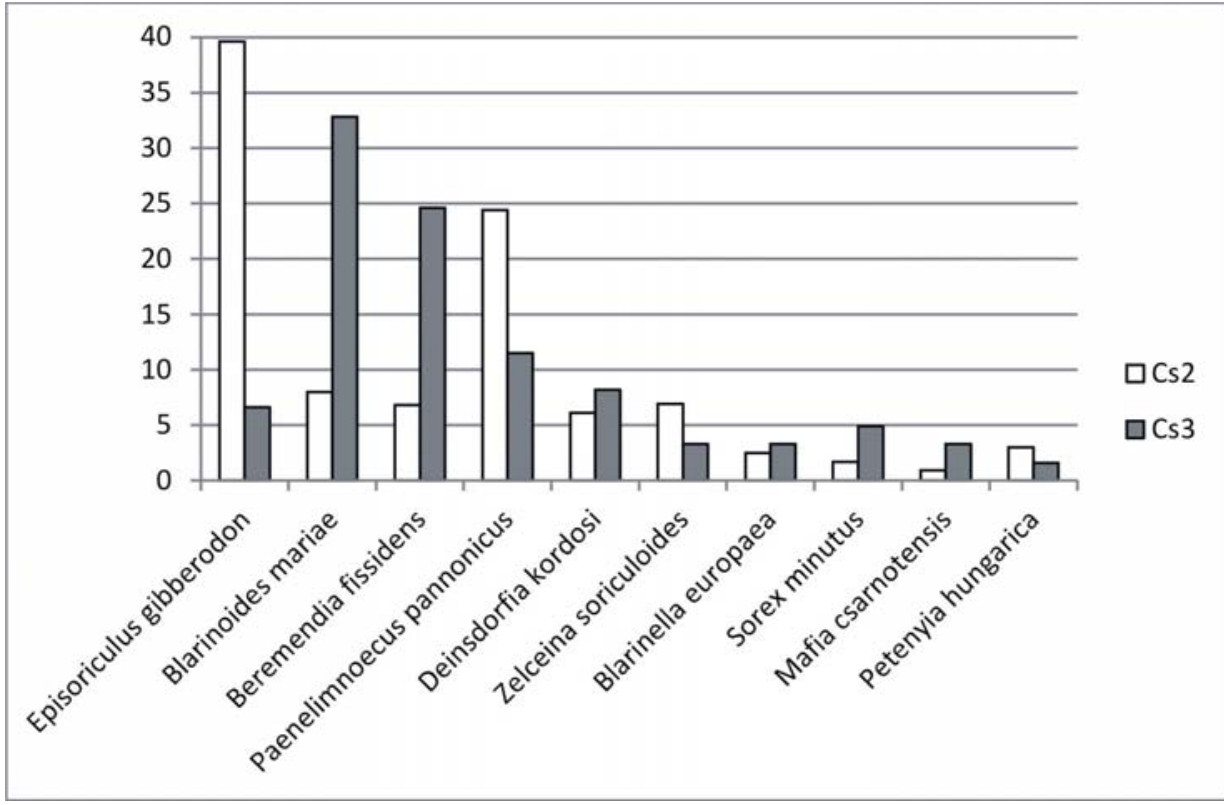

Fig. 16. Comparison of the Sorex fauna of the Csarnóta 2 and 3 localities. Cs 2 = Csarnóta 2, ratio of condyles (\%), after REUMER 1984, p.127; Cs3 = Csarnóta 3, ratio of MNI (\%) according to the present study

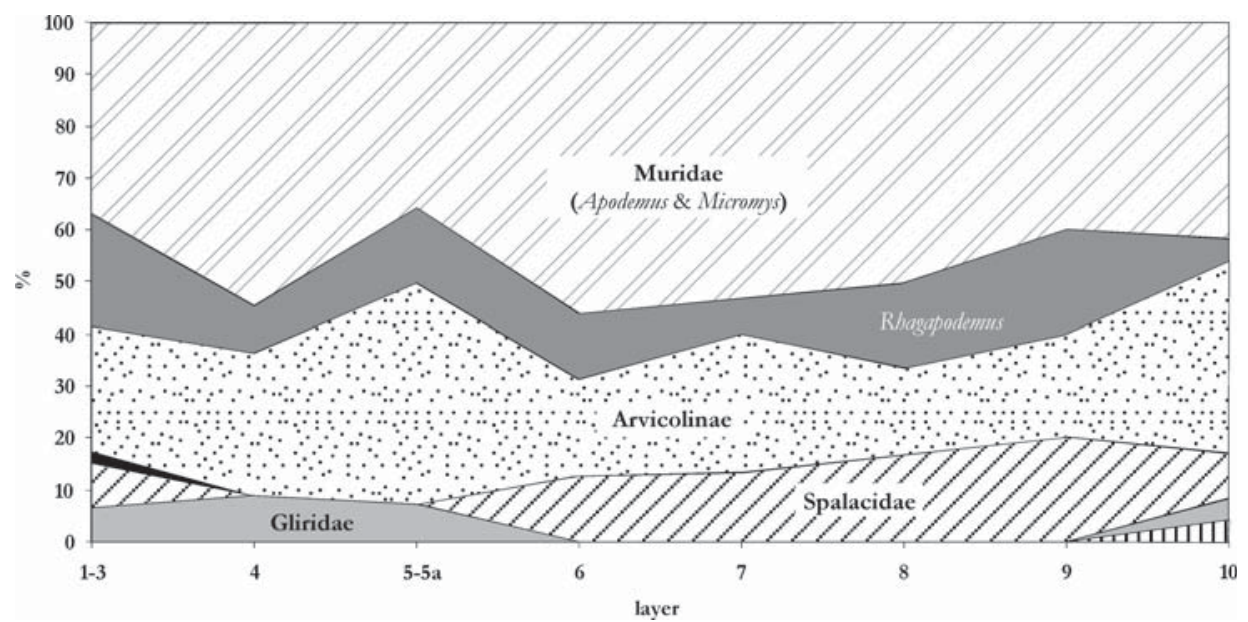

Fig. 17. Percentage of rodents in the Csarnóta 3 locality. Vertical stripes = Sciuridae; black $=$ Cricetinae 
the Csarnóta 2 site (Fig. 17). Although, Muridae (Apodemus-Micromys) are still dominant, the ratio of voles and Rhagapodemus frequens is also significant. The ratio of the other groups (Sciuridae, Gliridae, Spalacidae, and Cricetinae) is insignificant, only the proportion of Spalacidae (layers 6-9) and Gliridae (layers 4-5) exceeds $10 \%$. This fauna composition indicates a rather closed ecotype, but it was more open than that typical in the bottom layers of Csarnóta 2. The accumulation of this fauna is probably a snapshot from a transitional period between the forest and the grassland vegetation.

This study confirms as a new result the presence of albanerpetontids in sediments of Csarnóta 3. Compared with Csarnóta 2, from where several hundred albanerpetontid bones are known, this palaeovertebrate site with its 27 isolated skulls and jaw bones is really poor. Nevertheless, despite the small number of albanerpetontid remains, the fossils represent the diagnostic features of Albanerpeton pannonicum.

Among the studied 10 layers of Csarnóta 3 albanerpetontid fossils have not been unearthed from the strata 1-2 (top of the series) and 4-5. Even though, the levels 1-2 do not have albanerpetontid fossils, it cannot be claimed that this group became extinct by that time because its remains are also absent from the strata 4-5. This fact can be more readily explained by the small number of fossils, which is probably due to the different depositional environment of Csarnóta 2.

KRETzor (1962) previously mentioned remains of bufonid toads and snakes from Csarnóta 3. Preliminary analysis of the herpetofauna of this site revealed that the bones of the lizards Lacerta and Ophisaurus are present in all layers but the former genus is significantly more abundant. The lacertids are present in the largest numbers in layers 3-7, while the presence of Ophisaurus is uniformly low. The abundance of Lacerta bones in the above mentioned layers may be the result of extraordinary events, for example, an abrupt climate change (e.g. too rapid melting of snow or early heavy rains) during their hibernation (BEHRENSMEYER 1984, ANDREws 1990). At times of such accumulation a given population is overrepresented (BEHRENSMEYER 1991). Snakes and colubrids are the most abundant in the five uppermost layers. In the tenth layer the vertebrae of the Elaphe genus dominate but from the fifth level the bones of the Natrix genus prevail. Bones of turtles as well as some shell fragments were unearthed from strata 1-6. Salamanders are rare but appear in all layers except 2 and 8. The bones of the toad Bufo and the spadefoot Pelobates are present in relatively large numbers in all layers, whilst ranid frogs are rare (layers 1, 5 and 10). It was mentioned above that the bones of Albanerpeton pannonicum are not known from all layers (the reason for this is not known exactly), but it is the most frequent in about the middle of the section (layer 6). 


\section{CONCLUSIONS}

The above described fossil premaxillae, maxillae, dentaries, frontals, lacrimal and jugal from Csarnóta 3 referred to as Albanerpeton pannonicum represent the late Pliocene (i.e. the geologically youngest) record for this species from this so far tangentially studied locality situated near the type locality of this species. Csarnóta 3, based on its small mammalian fauna, is contemporaneous with the upper part of the section of site 2 ( $\mathrm{MN} 16 \mathrm{~A})$.

Though, the Csarnóta 3 albanerpetontid fossil assemblage is small, all studied remains are informative on species or at least on genus level.

Albanerpetontid remains assigned to Albanerpeton pannonicum were not found in all layers, for unknown reasons. Albanerpeton bones are the most abundant in layer 6.

Lacertid lizards dominate among the studied herpetofauna, but the presence of Ophisaurus, frogs, toads and snakes is also observable, while the bones of turtles and salamanders are rare.

The bones of snakes are the most abundant in the uppermost three layers but the dominance of Natrix begins to increase from the fifth layer.

On the basis of palaeoecological analysis of the small mammalian assemblage, the material of the Csarnóta 3 locality had presumably accumulated during a transitional period between forest and grassland vegetation.

Acknowledgements - The authors are grateful to Mihály Gasparik (Department of Palaeontology and Geology, Hungarian Natural History Museum), who generously made available the fossils that are reported herein. We are also grateful to Eszter Veszelinov (Department of Foreign Languages, Szent István University, Budapest), and Boglárka Erdei (Botanical Department, Hungarian Natural History Museum) who helped to improve the English text. We are also deeply grateful to reviewer, Márton Venczel (Țării Crişurilor Museum, Oradea, Romania) for his valuable comments and suggestions, which improved this paper. This is MTA-MTM-ELTE Paleo contribution No. 213.

\section{REFERENCES}

Anderson J. S., Reisz R., Scott D., Fröbisch N. B. \& Sumida S. S. 2008: A stem batrachian from the Early Permian of Texas and origin of frogs and salamanders. - Nature 453: 515518. http://dx.doi.org/10.1038/nature06865

ANDrews P. 1990: Owls, caves and fossils. - Natural History Museum Publications, London, 231 pp.

Augustí J., Cabrera L., Garcés M., Krijgsman W., Oms O. \& Parés J. M. 2001: A calibrated mammal scale for the Neogene of Western Europe. State of the art. - Earth-Science Reviews 52: 247-260.

Behrensmeyer A. K. 1984: Taphonomy and the fossil record: The complex processes that preserve organic remains in rocks also leave their own traces, adding another dimension of information to fossil samples. - American Scientist 72(6): 558-566. 
BeHRENSMEYER A. K. 1991: Terrestrial vertebrate accumulations. - Releasing the data Locked in the Fossil Record 9, Plenum Press, New York, pp. 291-335.

Botka D. \& Mészáros L. 2014: Beremendia (Mammalia, Soricidae) remains from the late Early Pleistocene Somssich Hill 2 locality (Southern Hungary) and their taxonomic, biostratigraphical, palaeoecological and palaeobiogeographical relations. - Fragmenta Palaeontologica Hungarica 31: 83-115. http://dx.doi.org/10.17111/FragmPalHung.2014.31.83

Delfino M. \& SAlA B. 2007: Late Pliocene Albanerpetontidae (Lissamphibia) from Italy. Journal of Vertebrate Paleontology 27(3): 716-719. http://dx.doi.org/10.1671/0272-4634(2007)27[716:LPALFI]2.0.CO;2

Evans S. E. \& Milner A. R. 1994: Middle Jurassic microvertebrate assemblages from the British Isles. - In: Fraser N. C. \& SuEs H.-D. (eds): In the shadow of the dinosaurs: Early Mesozoic tetrapods. Cambridge University Press, New York, pp. 303-321.

Fox R. C. \& NAYLOR B. G. 1982: A reconsideration of the relationships of the fossil amphibian Albanerpeton. - Canadian Journal of Earth Sciences 19(1): 118-128. http://dx.doi.org/10.1139/e82-009

GARDNER J. D. 1999: The amphibian Albanerpeton arthridion and the Aptian-Albian biogeography of albanerpetontids. - Palaeontology 42(3): 529-544. http://dx.doi.org/10.1111/1475-4983.00083

GARDNER J. D. 2001: Monophyly and affinities of albanerpetontid amphibians (Temnospondyli; Lissamphibia). - Zoological Journal of the Linnean Society 131(3): 309-352. http://dx.doi.org/10.1111/j.1096-3642.2001.tb02240.x

GARDNer J. D. \& Böhme M. 2008: Review of the Albanerpetontidae (Lissamphibia), with comments on the paleoecological preferences of European Tertiary albanerpetontids. - In: SANKEY J. T. \& BASzIO T. (eds): Vertebrate microfossil assemblages: their role in paleoecology and paleobiogeography, Indiana University Press, Bloomington, Indiana, pp. 178-218.

JÁnossy D. 1986: Pleistocene vertebrate faunas of Hungary. - Akadémiai Kiadó, Budapest and Elsevier Sciences Publishers, Amsterdam, Oxford, New York, Tokyo, 208 pp.

KRETzor M. 1959: Insectivoren Nagetiere und Lagomorphen der jüngstpliozänen Fauna von Csarnóta im Villányer Gebirge (Südungarn). - Vertebrata Hungarica 1: 237-246.

Kretzoi M. 1962: A csarnótai fauna és faunaszint. [The Csarnótian fauna and fauna level.] $-A$ Földtani Intézet Évi Jelentése 1959-ről: 297-343.

Kretzoi M. \& PÉcsi M. 1982: A Pannóniai-medence pliocén és pleisztocén időszakának tagolása. [Subdivision of the Pliocene and Pleistocene period of the Pannonian Basin.] - Publicationes, Academia Scientiarium Hungarica, Institutum Geographicum 394: 300-326.

López-González F., Grandal-d’Anglade A. \& Vidal-Romaní J. R. 2006: Deciphering bone depositional sequences in caves through the study of manganese coatings. - Journal of Archeological Science 33: 707-717. http://dx.doi.org/10.1016/j.jas.2005.10.006

Maddin H. C., Venczel M., Gardner J. D. \& Rage J.-C. 2013: Micro-computed tomography study of a three-dimensionally preserved neurocranium of Albanerpeton (Lissamphibia, Albanerpetontidae) from the Pliocene of Hungary. - Journal of Vertebrate Paleontology 33(3): 568-587. http://dx.doi.org/10.1080/02724634.2013.722899

Marjanović D. \& LAURin M. 2013: An updated paleontological timetree of lissamphibians, with comments on the anatomy of Jurassic crown-group salamanders (Urodela). - Historical Biology 26(4): 535-550. http://dx.doi.org/10.1080/08912963.2013.797972

McGowan G. J. \& Evans S. E. 1995: Albanerpetontid amphibians from the Cretaceous of Spain. - Nature 373(6510): 143-145. http://dx.doi.org/10.1038/373143a0

MeIn P. 1975: Resultats du Groupe de Travail des Vertebres. - In: SENEŠ J. D. (ed.): Report on Activity of the RCMNS Working Groups (1971-1975), Bratislava, pp. 78-81. 
MLí KovsKÝ J. 2001: Late Cenozoic biostratigraphy of Europe: mammal zones and the fossil record of birds. - Lynx (Praha) n. s. 32: 279-294.

Reumer J. W. F. 1984: Ruscinian and early Pleistocene Soricidae (Insectivora, Mammalia) from Tegelen (The Netherlands) and Hungary. - Scripta Geologica 73: 1-173.

RZEBi K-KowALSKA B. 1995: Climate and history of European shrews (family Soricidae). - Acta Zoologica Cracoviensia 38(1): 95-107.

Rzebi K-Kowalska B. \& Popov V. V. 2005: Bulgaria. - In: Hoek Ostende L. W. van Den, DouKAS C. S. \& Reumer J. W. F. (eds): The Fossil Record of the Eurasian Neogene Insectivores (Erinaceomorpha, Soricomorpha, Mammalia), Part I. - Scripta Geologica Special Issue 5: 31-35.

Sweetman S. C. \& Gardner J. D. 2013: A new albanerpetontid amphibian from the Barremian (Early Cretaceous) Wessex Formation of the Isle of Wight, southern England. - Acta Paleontologica Polonica 58(2): 295-324. http://dx.doi.org/10.4202/app.2011.0109

Szentesi Z., Gardner J. D. \& Venczel M. 2013: Albanerpetontid amphibians from the Late Cretaceous (Santonian) of Iharkút, Hungary, with remarks on regional differences in Late Cretaceous Laurasian amphibian assemblages 1, 2. - Journal of Canadian Earth Sciences 50: 268-281. http://dx.doi.org/10.1139/e2012-024

VENCZEL M. \& GARDNER J. D. 2005: The geologically youngest albanerpetontid amphibian, from the Lower Pliocene of Hungary. - Palaeontology 48(6): 1273-1300. http://dx.doi.org/10.1111/j.1475-4983.2005.00512.x

VICZIÁN I. 2002: Clay mineralogy of Quaternary sediments covering Mountainous and hilly areas of Hungary. - Acta Geologica Hungarica 45(3): 265-286. 